others, than in any country in Europe. It is not wonderful, therefore, that even now some of the Danes should be far ahead, and that as Prince Christian had a taste for natural history, he should have a splendid private collection, and that the curator of his museum (containing above 8,000 specimens of living shells), Dr. Beck, should be one of the two or three best conchologists in the world. But besides this, Copenhagen possesses in its different museums most of the identical shells which Linnæus described in the edition of his 'Systema Naturæ' published during his life ; and here therefore alone, we can verify incontestably the species which he really described and named. As Lamarck and others have in very many cases mistaken the shells which Linnæus meant, great confusion has arisen, and it is here alone that this confusion can most readily be cleared up.

"I am going over with Beck an examination of all the fossil species identified by Deshayes with living shells, and it will probably lead to many modifications of my views, at least many of my details, also to many new views which I shall perhaps have to test at Paris before I return."

\section{Edge's Pendulum for Ships}

IN 1837, the Society of Arts awarded a silver medal to Adolphus George Edge, a mate in the Royal Navy, for his invention of a pendulum for showing the inclination of a ship when under sail, which could be used for regulating the elevation or depression of the guns. It was tried with favourable results in the Inconstant and Pique, and at the end of June 1837 Rear-Admiral F. J. Maitland wrote to the Secretary of the Admiralty, from the Victory at Portsmouth, saying that as Edge's pendulum had shown its great superiority "to two other pendulums tried against it in the Portsmouth Yacht, I am desirous that my intended flag-ship the Wellesley should be supplied with it; and I request you to be pleased to obtain permission for one to be made for me in Portsmouth Yard". A example of the pendulum was placed in the repository of the Society of Arts.

\section{The Endless Ladder}

UNDER this title the Gentleman's Magazine for June 1837 gives the following description of what appears to be a prototype of the moving staircase. "A patent has recently been obtained for a most ingenious and useful machine adapted to mining and many other purposes, where the main object is to raise or lower weights or packages in constant succession. This simple but very effectual contrivance consists of an endless ladder, made either of chain or rope, which passes under and over two revolving drums or cylinders, mounted upon horizontal axes ; one placed at the bottom, and the other at the top of a shaft or plane, to and from which the ladder is intended to reach. A continuous motion being given to either of the cylinders by the power of steam or animal force, the endless ropes or chains furnished with horizontal stairs like those of a common ladder are made to circulate over the revolving cylinders by which they are distended, so that one part of this endless ladder is continually ascending with a slow but uniform motion from the lowermost of the cylinders to the uppermost, whilst vice versa the other part of the ladder is descending to the lowermost in an uninterrupted circulation."

\section{University Events}

Birmingham.-The new A. E. Hills chemistry building is to be opened formally by the donor on July 7. The opening address is being given by Sir Frederick Gowland Hopkins.

GLasgow.-Prof. G. G. Henderson has presented t) the University a valuable collection of books and reprints on chemistry, and also an interesting series of engravings and photographs.

The following candidates were awarded the degree of D.Sc. at the graduation ceremony held on June 16 : J. Bell (thesis : "Heavy Water and the Structure of Crystalline Hydrates", with additional paper) ; J. D. Loudon (thesis: "The Cationoid Reactivity of Nitrodiphenylsulphones", with additional papers); Anne H. McAllister (thesis: "Clinical Studies in Speech Therapy").

Honorary degrees were conferred on the following, among others: LL.D., Prof. J. Boeke, professor of histology and embryology, University of Utrecht; J. M. Cowan, physician, Glasgow ; Prof. T. K. Monro, emeritus professor of medicine, University of Glasgow ; Sir Robert Muir, emeritus professor of pathology, University of Glasgow; Sir Albert Seward, emeritus professor of botany, University of Cambridge; Prof. R. Stockman, emeritus professor of materia medica, University of Glasgow.

Liverpool.-On June 4, honorary degrees were conferred on the following, among others: LI.D., Lord Leverhulme, formerly pro-chancellor of the University; Sir Hector Hetherington, principal and vice-chancellor of the University of Glasgow, formerly vice-chancellor of the University of Liverpool; $D . S c$., Prof. C. T. R. Wilson, formerly Jacksonian professor of natural philosophy, Cambridge ; D.Eng., Mr. A. P. M. Fleming, director and manager of the research and education departments of the Metropolitan-Vickers Electrical Co., Ltd.; Litt. D., M. René Dussaud, Department of Syrian and Palestinian Antiquities, Louvre Museum.

MANCHESTER.-In addition to the grant of $£ 5,000$, recently announced, in aid of the biochemical research directed by Prof. I. M. Heilbron, the Chemistry Department has now received from the Rockefeller Foundation a further grant of $£ 300$ a year for two years in aid of the application, under Prof. M. Polanyi, of physico-chemical methods to the elucidation of problems of biological interest.

A chair of theoretical physics has been instituted in the University to which Prof. D. R. Hartree, at present Beyer professor of applied mathematics, has been appointed.

Dr. J. G. Woolham has been appointed honorary assistant lecturer in physiology. Dr. J. M. Jackson and Dr. J. A. Todd have resigned their posts in the Department of Mathematics on appointment as lecturers in Westfield College, University of London, and the University of Cambridge respectively.

OxFord.-At Encænia on June 23, honorary degrees were conferred upon the following, among others :-D.C.L.: The Right Hon. W. G. A. Ormsby-Gore, Hon. R. H. Brand and Sir Herbert Baker. D.Sc. : Prof. Walter Nernst. D.Litt. : Dr. G. P. Gooch.

Prof. J. H. Hutton, of Cambridge, has been appointed Frazer lecturer in social anthropology for 1938 . 